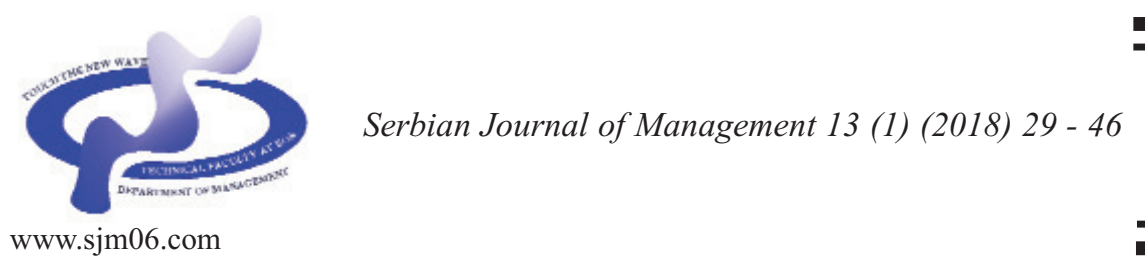

\title{
SUCCEEDING A FAMILY BUSINESS IN A TRANSITION ECONOMY: FOLLOWING BUSINESS GOALS OR DO IT IN MY OWN WAY?
}

\author{
Predrag Ljubotina $^{a^{*}}$, Doris Gomezelj Omerzel ${ }^{a}$ and Jaka Vadnjal ${ }^{b}$ \\ ${ }^{a}$ University of Primorska, Titov trg 4, 6000 Koper, Slovenia

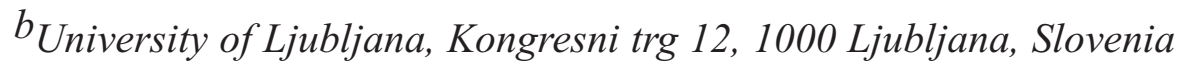

(Received 07 July 2017; accepted 22 January 2018)

\begin{abstract}
Students with family business background have three options once it comes to career path decision. This makes the career choice more complex compared to a classical dilemma between seeking an employment and starting a new venture. Based on GUESSS 2013/14 survey conducted in 34 countries with 109000 participants the influence of personal factors influencing student's career choice in transition countries and countries with developed market economy in Europe was analyzed. By drawing on theory of planned behavior, risk attitudes and family business performance the difference between the two observed groups was investigated. It was found that common denominator of almost fifty years of planned economy in transition countries does influence their career choice intentions especially in terms of personal behavior control, subjective norms and risk attitudes. Findings, based on comparative approach, suggest that environmental context is an important influencing factor which should be considered in further studies of the field.
\end{abstract}

Keywords: family business, international study, succession, transition economy, GUESSS survey

\section{INTRODUCTION}

Family business played a significant role in development of western civilization starting from ancient time economies until nowadays when family members are in control of not only small businesses but also many modern large and even global corporations (Bird et al., 2002). Family businesses are the mail pillars of any economy with large contribution to country's GDP (Kota \& Singh, 2016). It is just one of

\footnotetext{
* Corresponding author: predrag.ljubotina@gmail.com
}

DOI: $10.5937 /$ sjm13-14474 
the reasons why, in a modern economy, it is even more important to identify and to support individuals in their entrepreneurial intentions (Wennekers et al., 2005). Consequently, we need further theory development to better explain and understand entrepreneurial intentions of individuals (Douglas, 2013). This is especially true when speaking about the forerunners of entrepreneurial intentions (Liñán \& Chen, 2009).

Following this guidelines the following research gaps were recognized. First, studies of young people career decision mainly focus on career decision dilemma between employment and entrepreneurial career. Young people coming from families with family business background are in a specific situation. When it comes to career decision instead of thinking about the entrepreneurial or employment dilemma they are facing a trilemma with an additional possibility offered by potential family business succession. There are some recent studies, which investigate the trilemma of students with family business background (Zellweger et al., 2011). However, this field is still emerging and needs further research especially considering the impact of the business environment.

Second, majority of entrepreneurial intention studies, which apply the theory of planned behaviour, does not try to build a multilevel model, which could be more explanatory for specific target groups like students with family business background. Multilevel quantitative research of family business succession is still scarce, thus there is a need for the development of empirical research on the field (Baù et al., 2013). Multilevel perspective is important since resistance to succession at different levels represents one of key reasons for failure to plan the succession in family firms (Handler \& Kram, 1988). Our model is partly built on thesis that career choice is determined by three factors: Individual (psychographic), social (family support, culture, role models) and economic (employment opportunities, networks) (Dyer, 1986). Recent studies confirmed multilevel nature of succession issues, which are function of several variables like property, management, successors, leadership, age of the business, complexity of the business, financial performance and proximity of succession (Ramadani \& Hoy, 2013).

Finally (third), it is noted that there are not enough studies which analyze different geopolitical groups. Vast majority of studies, which are dealing with family business succession are geographically speaking single-region studies (Agarwal et al., 2016). Studies have already identified that formerly planned, so-called transition economies are worth studying since succession research could have additional benefit from the higher attention to context (Baù et al., 2013).

This paper carries an ambition to close the three gaps by investigating career intentions of students with family business background by building a regression model, which includes three TPB parameters, perception of family business performance and individual's attitude towards risk. In addition, the influence of risk perception on attitudes towards self-employment and perceive behavioural control is analyzed, a construct suggested by previous studies (Quintal et al., 2010). Our dataset is the result of multinational GUESSS 2013/2014 research (Global University Entrepreneurial Spirit Student Survey). European students from countries with transition economies are investigated and compared with their peers from European geo-political region with 
traditional market economy. The empirical background is built on the positive attitude towards repetition of studies with different samples and socio-economic context (Davidsson, 2004).

\section{THEORETICAL BACKGROUND AND HYPOTHESES DEVELOPMENT}

Management and ownership transition is one of the biggest challenges for family and the business (Blumentritt at al., 2012). It is not an easy task to attract the next generation and keep it motivated for family business continuation. Researchers have noted several factors influencing the process and the field is still emerging considering its importance to economy (Neubauer \& Lank, 2016). Studies have also shown that the willingness of the heir to take over the business enhances the satisfaction with the succession process itself (Sharma et al., 2003).

Evidence suggests that younger population is more attracted to entrepreneurial career, which further leads to the conclusion that student population is an important entrepreneurship research target. At this stage of life attitude towards entrepreneurial career is formed (Shirokova et al., 2016).

Students deriving from family businesses have a specific background, which differentiate them from their colleges. Entrepreneurial parent can influence heir's career choices with the business existence which can provides a stabile starting point for the new entrepreneur. They can provide customers, supply network and other social capital (Laspita et al., 2012). Family business also offers a good insight into entrepreneurial activities and decisionmaking process. This can make heir's career decision easier as entrepreneurial knowledge will make them less sensitive and less afraid of potential failure.

Previous researches had shown that geographical context affects behaviour and does influence the family business succession (Scholes et al., 2007; Zellweger et al., 2011). Despite that fact there still is a gap on the field of socio-cultural factors combined with individual aspirations which together influence potential successor's career decision, especially in countries, which are still developing market economy (Agarwal et al., 2016). In this context, transition countries represent a useful research sample for assessing changes of economic systems from one type to another (Estrin et al., 2009). For this reason, our study is conducted in transition economies with the main aim to compare them with the developed market economies group as a reference for their economic system change in process.

According to the theory of planned behaviour all behaviours (such as entrepreneurial behaviour or selfemployment) are intentional and as such, predictable (Ajzen, 1991). Intentions directly affect behaviour, while attitudes affect intentions. Consequently, behaviour is best predicted by intentions (Krueger \& Carsrud, 1993). Theory of planned behaviour predicts intention towards behaviour with three attitudinal constructs: attitudes towards behaviour, subjective norms and perceived behavioural control. Several studies tested parts of the theory with self-employment career decision as target behaviour and confirmed it as a relevant and consistent method (Krueger Jr. et al., 2000; Lüthje \& Franke, 2011; Carr \& Sequeira, 2007). On the field of entrepreneurial research attitude towards self-employment is defined as the 
difference between personal perceptions of desirability of career alternatives. Subjective norms reflect perceptions of important people opinion about subject's intention to become an entrepreneur or successor (Krueger Jr. et al., 2000). Perceived behavioural control as a third factor indicates the perceived ability to become selfemployed (Kolvereid, 1996). Still there are gaps in the research field, which are calling for additional studies. Family business succession is surely one of the important segments. Based on Kolvereid (1996) notes, family business may impact the career choice by influencing the formation of three TPB dimensions. This claim has already been confirmed (Laspita et al., 2012; Zellweger et al., 2011). Potential successor has a career trilemma and two of his alternatives are both considered as selfemployment (new start-up and family business take over). Prior exposure to the entrepreneurial environment is considered to be an important predictor of selfemployment career choice (Krueger \& Carsrud, 1993; Zellweger et al., 2011). From what was said above, H1 is developed: Higher levels of subjective norms, attitudes towards self-employment and perceived behavioural control result in preferring founding own new business over the succession and succession over the employment. (Krueger \& Carsrud, 1993; Krueger Jr. et al., 2000; Lüthje \& Franke, 2011; Carr \& Sequeira, 2007)

Risk taking is an important dimension of business. It has a very high impact on family business especially having in mind that family and business constantly interlace. Researchers confirmed that the extent of involvement in risky activities is influenced by ownership and governance of the business. It is believed that family business are likely to handle risk in a different way partly due to the fact that management and ownership are usually not clearly separated (Senegović et al., 2015). Individuals do consider risk when evaluating their career alternatives and options. Self-employment intention is higher for individuals with more positive attitudes towards risk. So, the higher individual's risk tolerance, the more intense is self-employment intention (Douglas \& Shepherd, 2002).

Previous studies showed that entrepreneurial attitudes are partly evolved as the result of risk and uncertainty tolerance (Desislava \& Tarrazon, 2010). Uncertainty avoidance is also one of distinctive cultural dimensions (Hofstede, 2003) as it is defined as "the extent to which the members of a culture feel threatened by uncertain or unknown situations" (Hofstede, 1991). This is one of our guidelines for separating transition and market based economies. Societies with low uncertainty avoidance are expected to be more supportive for new entrepreneurial activities due to favourable cultural conditions (Autio et al., 2013).

Since family business, which is the subject of succession process is already developed to some extent we consider founding career to be heir's riskiest career option (Laspita et al., 2012). Taking into consideration the views and findings of some relevant previous research $\mathbf{H 2}$ is proposed: The more positive student's attitude towards risk the higher is the individual's preference for a founding career to succession and succession to employment. (Douglas \& Shepherd, 2002; Hofstede, 2003; Autio et al., 2013)

Previous studies have frequently analysed the relation between succession and postsuccession firm performance (Williams Jr., 2015; Eddleston et al., 2008). Relationship 
between pre-performance and succession intention has not been investigated often. Sustainable family business growth is usually driven by long-term vision of generating wealth (Habbershon et al., 2003). It is in the interest of a long-term family business survival that all family members perceive the business as a successful performer (Olson et al., 2003). In this way, family business performance can be a proxy for measuring the long-term stability potential heir.

Successful entrepreneurial parents as role models can impose a significant impact on heir's career choice (Chlosta et al., 2012). It is already known that prior company performance is not significantly related to the likelihood of nominating a family successor (Bocatto et al., 2010). In some cases successful past performance can even be an obstacle for further entrepreneurial activities (Zahra, 2005). Succession surely is one among the most important entrepreneurial activities in family businesses. It is generally agreed that business performance is a valid predictor for the effectiveness of business succession (Morris et al., 1997). Yet, we could not find any investigation of heir's perception of family business performance and its impact on career decision. Perception of family business performance is highly subjective. Olson et al. (2003) finds that family members will more likely be engaged in a successful family business while business problems often negatively influence functional integrity of the family. Derived from the previous research above $\mathbf{H 3}$ was constructed: More positive student's perception of family business performance leads to higher level of preference for a founding career to succession and succession to employment. (Olson et al.,
2003; Chlosta et al., 2012; Bocatto et al., 2010; Morris et al., 1997)

According to definition, perceived risk is seen as an individual's subjective feeling of uncertainty that the consequences of decision will be favourable (Cox, 1967). As such, perceived risk is understood as expectation of a potential loss and it is likely to negatively influence attitudes towards behaviour (Quintal et al., 2010). Similarly, since uncertainty is a function of perceived risk (Cox, 1967), it is likely to influence perceived behavioural control over the intended activity.

With the addition of perceived risk we want to examine the relationship between the perceived risk and theory of planned behaviour construct in relation to student's self-employment in H4: Perceived risk regarding the entrepreneurial career is lower with higher levels of attitudes towards selfemployment and perceived behavioural control. (Quintal et al., 2010; Cox, 1967)

\section{METHODS}

\subsection{Participants and procedures}

Our research data is based on GUESSS 2013/2014 dataset, which partly covers the family business succession issues. The dataset contains more than 109.000 student respondents from 34 countries. The anonymous on-line survey is identificationbased to prevent multiple responses bias.

For the purpose of our analysis, 23.485 European students with family business background are divided in the transition group (5.964 students from 5 countries) and the market economy (17.521 students from 13 countries) group. Transition countries are in the process of economic system change 
(Bezemer, 2006). Today, they are in different stages of socio-economic development and transformation process towards the market economy. However, they all share similar past behaviour patterns based on centrally planned economies.

In our paper Slovenia, Romania, Poland, Estonia and Hungary are classified as transition economies according to International Monetary Fund classification (Roaf et al., 2014). Based on the same source our reference market group consists of Great Britain, Germany, Luxemburg, Netherlands, Switzerland, Austria, Belgium, Denmark, Spain, Finland, France, Italy and Portugal. Considering that environmental context differs greatly in two groups, it is expected that this will result in different individual's entrepreneurial intention.

Nowadays we still do not have a single definition for family business available. This paper adopts the definition that a family business is a business where majority share is owned by one or more members of the same family (Barnes \& Hershon, 1976). Based on such definition this study includes only students with one or both self-employed parents. Students who already established their own company are excluded from the analysis to allow a prospective view and avoid so-called survivor bias from which retrospective studies might suffer when interviewing entrepreneurs about motives after they already started a firm (Davidsson, 2004; Gartner, 1989). After the reduction, the "transition" group contained 3.979

Table 1. Descriptive sample statistics

\begin{tabular}{lrrrr}
\hline & & Transition & & Market \\
\cline { 2 - 5 } & Mean & S.D. & Mean & S.D. \\
\hline age & 22.20 & 3.35 & 23.00 & 3,65 \\
motivation for self-employment & 5.56 & 0.87 & 5.38 & 0.82 \\
university support & 4.11 & 1.55 & 3.91 & 1.51 \\
attitude towards risk & 4.81 & 1.54 & 4.57 & 1.47 \\
years of family business ownership & 14.77 & 12.24 & 19.20 & 13.21 \\
family business performance & 4.07 & 1.55 & 3.97 & 1.48 \\
\hline
\end{tabular}

Table 2. Sample group frequencies

\begin{tabular}{lcc}
\hline & Transition & Market \\
\hline Gender & & \\
mail & $37.1 \%$ & $39.6 \%$ \\
femail & $62.9 \%$ & $60.4 \%$ \\
\hline Already employed & \\
yes & $29.6 \%$ & $38.4 \%$ \\
no & $70.4 \%$ & $61.6 \%$ \\
\hline Attended courses on entrepreneurship & & \\
yes & $66.3 \%$ & $27.1 \%$ \\
no & $33.7 \%$ & $72.9 \%$ \\
\hline Already been working in family firm & & \\
yes & $51.9 \%$ & $46.3 \%$ \\
no & $48.1 \%$ & $53.7 \%$ \\
\hline
\end{tabular}


respondents and reference "market" group 6.617 respondents. Table 1 shows the two group descriptive statistics, which are comparable. There is a difference in average time of ownership, which is somehow expected since transition process in Europe got place in 1990, which limits business development time span to only 25 years.

The sample is additionally explained in Table 2. The gender structure in both groups is very similar. Students from countries with developed market economy are more engaged in regular jobs next to their studies. On the other side, more students from transition countries attended at least one entrepreneurship course. Approximately half of students in both groups already had some working experiences in their parent's family businesses.

The independent variable is categorical and has three possible dimensions, which lead towards multivariate multinomial logistic regression as the most appropriate method for data analysis. Multivariate approach allows us to capture the multilevel complexity of an individual career choice while multinomial logistic method allows more than two discreet solutions for independent variable. All proposed hypotheses have succession as a central category, so it is used as a reference category for the purpose of regression coefficients interpretation. For the last hypotheses (H4) linear regression is used on dataset. Proposed methods have been previously used for the purpose of explaining similar models (Quintal et al., 2010; Zellweger et al., 2011).

The sample had to be limited to intergenerational family firm management transfer. For this purpose, our respondents answered the question, "Are your parents currently self-employed or do they have a majority ownership in a company?" The analysis includes only students who answered: "Yes, mother", "Yes, father" or "Yes, both".

\subsection{Measures}

\subsubsection{Dependent variables}

The dependant variable for first three hypotheses is categorical with three possible solutions: (1) "employee",

"entrepreneur" or (3) "successor". Students were asked about their future career decision after their studies. The option "I don't know yet" is added, which allowed us to exclude undecided students and to avoid forced decisions with the goal of avoiding biased results from this source. For the purpose of testing the hypothesis 4 risk perception is used as the dependent variable.

\subsubsection{Independent variables}

The model consists of several independent variables. First, attitude towards self-employment (5 items), subjective norms (3 items) and perceived behavioural control (7 items) are used as components of the theory of planned behaviour construct. For the purpose of measuring the family business performance perception, students were asked to evaluate the firm's performance compared to competitors over the period of last three years. In order to do so, they were asked to consider five Likert scale based items: sales growth, profit growth, job creation, market share growth and innovativeness (Eddleston ea al., 2008). Respondent's personal risk attitude was measured using a general risk question ("I am generally a person who is fully prepared to take risks.") since it was accepted and confirmed as a reliable predictor of actual risky behaviour in 
connection with self-employment (Dohmen et al., 2011). Considering that the questionnaire was long it was convenient to use all reliable measures to make it easier for respondents to participate. Individual's risk perception as a situational factor was measured using three Likert items specifically related to self-employment (Pennings \& Wansink, 2004). All items are measured using 7-point Likert scale.

\subsubsection{Control variables}

In addition to independent variables, several control variables were included in the model: gender, study performance, student regular employment next to study, attendance of entrepreneurial courses, family business ownership duration and experience in working in a family firm. Previous studies showed that women are disadvantaged as successors (Schröder et al., 2011). According to Zellweger et al. (2011), women also have a higher likelihood for choosing employment before succession. Student's study performance self-assessment is included as a proxy for individual's perception of his potential possibilities on job market. Duration of family firm ownership is included in the model as a control variable since it might influence the offspring's perception of family business stability and value (Zellweger et al., 2012). Following same line of reasoning, the respondents were asked if they had a regular job next to their studies, if they attended courses of entrepreneurship and if they have already been working for family firm. The responses to these questions are included in the control model as two-dimensional dummy variables (Yes/No).

\section{RESULTS}

\subsection{Method validity}

Variance inflation factor (VIF) was calculated for each independent variable. VIF is close to 1 for all variables and it does not exceed 1.6 for any variable which leads us to the conclusion that multicollinearity does not appear to be a problem since it is well below the marginal value of 10.0 (Hair et al., 2010). It was confirmed that the variables were empirically distinct using Harman's single-factor test. In transition group one factor solution accounted for $34.67 \%$ of total variance while it reached $31.59 \%$ in the reference market group. Both sets of data (transition and market group) were tested with exploratory factor analysis to check scale constructions. Results revealed that all items uniquely load their respective factors with minimal factor loading of 0.475 . Pearson correlations are displayed in Table 3. Since all correlations are below 0.6 there is no indication of shared variance.

The potential common method bias problem is additionally mitigated by using a set of control variables. Participating students were assured strict confidentiality to avoid the potential influence of social desirability concerns (Podsakoff et al., 2003).

\subsection{Regresson results}

Results of multinomial logistic regression models for both groups are summarized in the Table 4.

Based on regression results our first hypotheses is partly confirmed. Higher attitude toward self-employment results with succession preference over employment 
Table 3. Pearson correlations

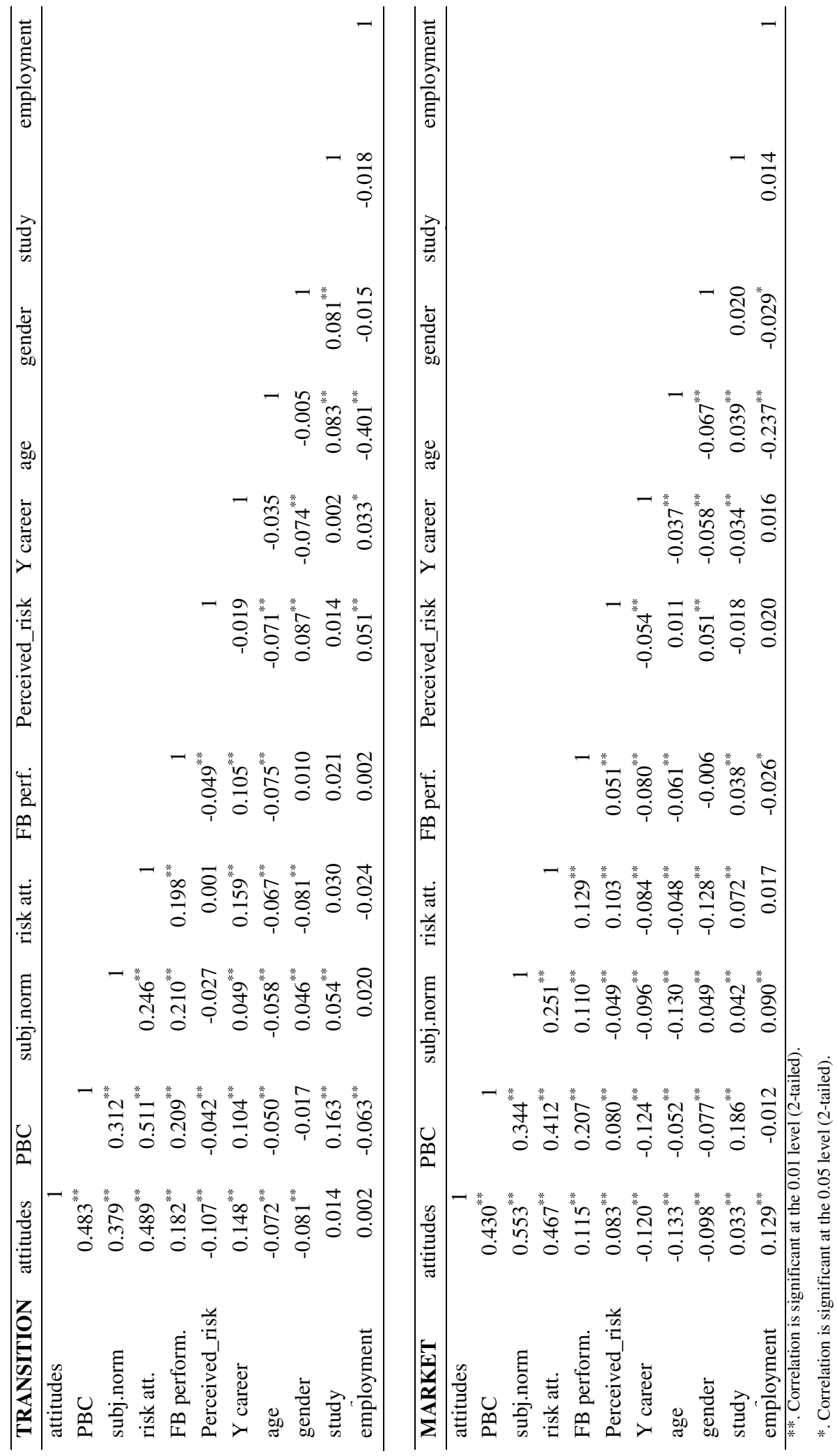


Table 4. Multinomial regression coefficients

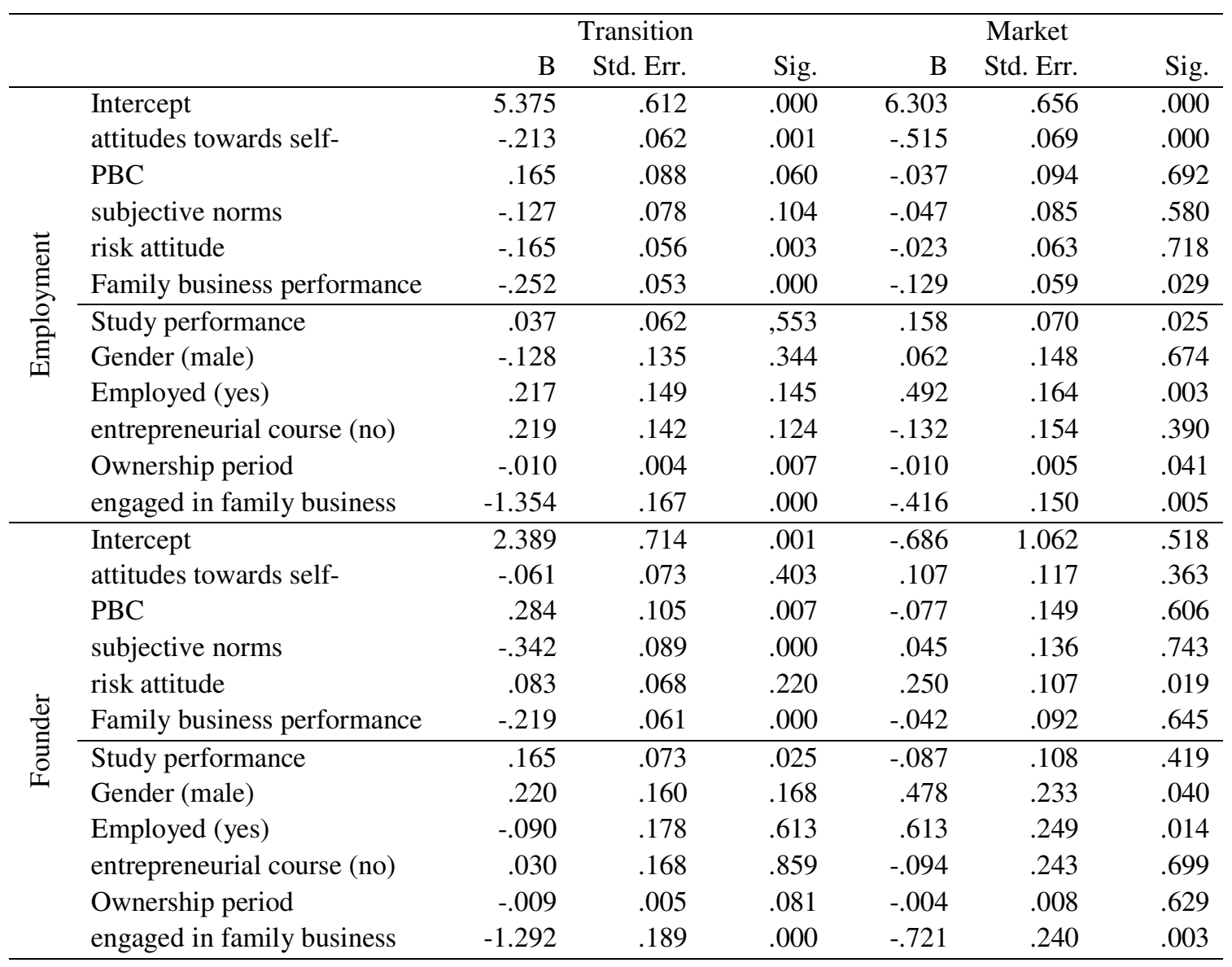

alternative in both groups, which is consistent with the hypothesis 1 . On the other side, students with higher attitudes towards self-employment prefer a new startup over succession in market group while transition group shows opposite result. Respondents with more positive perception of behavioural control (stronger perception of internal control over situation) prefer succession before both alternatives in transition countries. Result in market group where both alternatives are preferred over succession are completely opposite. The influence of subjective norms confirms the first hypotheses for both groups in most part. The only exception is a significant preference for succession to founding career in transition group $(B=-0.342)$.

Result of risk attitude analysis is consistent with the second hypotheses since both groups express founding preference to succession and succession to employment. This result is expected. It is noted that differences between employment and succession alternatives in market group and founding and succession in transition group are low and insignificant. Hypotheses 3 can be partly confirmed. Family business performance proved to be an important factor, influencing respondent's career choice in favour of succession compared to the two alternatives in both groups.

Table 5 shows results from analysing risk perception impact on attitudes towards self- 
Table 5. Risk perception regression results

\begin{tabular}{lrrrr}
\hline & \multicolumn{2}{c}{ Transition } & \multicolumn{2}{c}{ Market } \\
\cline { 2 - 5 } & attitude & PBC & attitude & PBC \\
\hline Mean value & 4.927 & 5.213 & 4.239 & 6.644 \\
Standard deviation & 1.556 & 0.998 & 1.637 & 0.963 \\
coeficient B & -0.124 & -0.031 & -0.157 & -0.096 \\
Standardized Beta & -0.107 & -0.042 & -0.120 & -0.124 \\
Significance & 0.000 & 0.009 & 0.000 & 0.000 \\
\hline
\end{tabular}

employment and perceived behavioural control. Since all correlations are negative (Stand. Beta) and statistically highly significant, the hypotheses 4 is confirmed.

Students from both groups with better self-assessed study performance will rather find a job than take over a family business. Respondents from transition countries will prefer new start-up to succession as well while in market group better students will more likely choose succession. Gender control variable shows some notable differences between genders and groups. Men compared to women are more likely to become founders than successors in both groups. When choosing between employment and succession, male students from transition countries will more likely decide to take over a family business while their mates from market group will rather find a job elsewhere. Transition countries students who have jobs alongside their studies will more likely choose employment before succession and succession before founding a new company. Their colleges from market group show significantly stronger dependence on this variable. They will opt for employment rather than succession as well while on the other side they are more likely to found a new company than choose a succession career.

Entrepreneurial courses influences on student's career decision are shown to be yet another factor of differentiation between the groups. Respondents from transition group, which attended at least one entrepreneurial course during studying, will more likely choose both alternatives to succession while their mates from countries with market economy will prefer succession over both alternatives. Results are not statistically significant in this part so it is not possible to draw any conclusions related to general population. The influence of family business ownership period on heir's career choice is not detected although results for both our groups are highly statistically significant in part where respondents from both regions prefer employment over succession.

Previous engagement in family business has a high and statistically significant impact on heir's career choice. Students from both groups who already have experience working in family firm will to a great extend prefer succession career to both other alternatives. This is true for both regions observed.

\section{DISCUSSION AND IMPLICATIONS}

Students with family business background experience a specific trilemma when choosing their career path. This paper contributes to better understanding the wider perspective of the problem they are confronted with. Having in mind the importance of multilevel perspective (Baù et 
al., 2013) three-dimensional model is tested based on Dyer's (1986) thesis that career choice is determined by individual, social and economic factors.

The present study results importantly contributes to better understanding of economic transition processes since we compared students with family business background from transition countries with their peers in countries with market economy. It is found that higher level of attitudes towards self-employment leads to succession as career choice compared with employment in both regions. However, relations are stronger in market economy region. This observation could be the result of relatively short entrepreneurial tradition in transition countries which disables heir's to gain enough confidence in family business. When observing founding and succession career alternatives we obtained opposite results. Students from market economies would rather find a job while their colleagues would more likely take over a family firm. The difference could be explained with the fact that students from market economies have considerably more promising opportunities on job market. Respondents from transition regions could feel more secure in their family business when comparing it with volatile local job market. According to results of this study, personal behavioural control (PBC) does not significantly influence student's career choice in market group. On the other side, it is found that transition group will prefer both alternatives over succession. These results lead us to the similar conclusion as mentioned previously. We believe that socioeconomic environment and most of all the stability of the system and the level of corruption have an important impact on student's career choice. Higher level of stability and lower corruption level means that PBC is less important when considering one's career path. In different condition, students will prefer option, which puts more control in their hands. In our case, employment and new start-up are both considered as such options since there are no family members and consequently no intrafamily relationships to manage. Similarly subjective norms showed to have almost no impact on the decision in market region while higher level of subjective norms means higher probability for succession career choice in transition countries. The conclusion is that developed market economy region is potentially more individualistic. In transition group the opinion of "important others" is considered as an important factor. Since the family usually expect their heir to take over the business, the results are somehow expected.

In transition countries, the higher level of risk attitude (person who will more likely take risk) leads to succession before employment. Same trend is detected in the reference market group but the coefficient was very low. Opposite result was detected when comparing founding and succession career. Students from market group who will more likely take risk prefer a new start-up before succession while a difference in transition region was not detected. It is assumed that funding career is viewed as more risky than succession in market economy while students in transition region connect both alternatives with similar risk levels. This is in favour of proposed standpoint according to which entrepreneurial tradition plays a significant role in taking career decision, which was also one of the decisive factors for doing this study.

Family business performance proved to 
be a significant factor in both groups. This result is expected since it gives feeling of long-term stability to the heir. Better performing family business is more attractive for heirs from both regions. However, a relatively low coefficient is noticed in market group when comparing founding and succession alternatives. This generally means that these students do not see the difference between the two career paths. Once they take the decision to be selfemployed, they do not consider positive family business performance to be more attractive that new start-up. The observation also shows higher level of sensibility for business performance in transition group. This could be understood in the context of previous research, which confirmed that the level of poverty in transition countries exposes the importance of family business performance for heir's future (Bezemer, 2006).

This paper confirms that perceived risk is in negative correlation with attitudes towards self-employment and perceived behavioural control. Such result was expected since situational risk perception was measured. The more risky the entrepreneurial career is perceived less positive attitudes are detected towards it. Similarly, respondents feel less capable to control the situation (lower PBC).

Control variables result shows that men are more likely to choose founder career over succession. This can be considered as an important guideline for present owners. Students who have a regular job beside their studies are much more likely to choose one of two alternatives to succession, which is additional important information to be considered by parents. It speaks in favour of engaging heirs in family business as soon as possible. This conclusion is additionally supported by the result of our corresponding control variable, which confirms a high correlation in favour of succession comparing to both alternatives in both regions. Regression coefficients are considerably higher in transition countries, which again confirm the importance on tradition. The longer is the regional entrepreneurial tradition the lower the impact of heir's engagement in family business on career decision. Considering the importance of small and medium sized enterprises nowadays, this finding should be considered by both, parents and government authorities. If we wish to improve the long-term stability of family firms, we have to educate potential successors about the important role they have for the economy.

Significant influence of study performance was detected in two cases. Better performing students in transition group will more likely found their own company than tale over family firm. In the market economy group better students prefer finding a job that succeeding a family business. Entrepreneurial courses are encouraging succession career choice in market economy while they promote both alternatives in transition countries. Based on this finding it is concluded that getting more familiar with entrepreneurship makes students in transition economies more insecure. It could be speculated that the reason for this lies in unstable social and political environment.

\section{CONCLUSION}

Each entrepreneurial process has to start with entrepreneurial intention in some point of time. Students are very close to that point since they are expected to start a professional career after their studies. This paper 
contributes to a growing research field dealing with a specific group of students with family business background and their complex career decisions, which results with their intentions becoming actions. The significance of those actions is growing in today's societies where small and medium sized businesses are regaining their importance for social and economic stability of societies.

\subsection{Limitations of the study}

For the purpose of this paper, GUESSS 2013/2014 cross-sectional data was used. We measured and studied Perceived factors and intentions were measured and studied at the same point of time. Consequently, it is difficult to draw conclusions related to causality. This could generate a potential shift of intentions since intentions might influence responders. Still, we strongly believe that the threat of reverse causality is low enough especially knowing that theory of planned behaviour with no doubt suggests, that causality goes only in one direction, from intentions to actions and not the other way around. The issue is additionally addressed by eliminating responders who are already engaged in their own business. Obtaining actual measures from sources other than self-assessment would also offer more insides. On the other side, it would also raise the complexity of the study and data collection. Still, the respondents are deeply involved in the problem as family members and potential successors.

The study is partly limited by the exclusion of job accessibility factor outside family business. This could also be an important contributing factor in the model. Family business succession is more or less expected and as such can be seen as guaranteed. Formal entry requirements for other job alternatives could presumably influence heir's career choice. We believe that the problem is successfully managed by offering three alternatives to our respondents, since they are related to different levels of entrepreneurial involvement.

\subsection{Future research}

This paper opens some questions, which could be addressed by future studies. Comparing models used in this paper with other recent studies shows that moderator set used is not exhaustive. In our case, it is limited by GUESSS data available. Further multilevel models should be tested including individual, environmental and maybe even emotional context. Since our results show that environmental context is an important influential factor, it should be modelled and analysed more in detail (job accessibility, university, family, siblings, etc.). Future studies should strive for a general multilevel model, which would define rigorous boundaries for theory of planned behaviour application on narrow student's career choice problem. This model should be applied on different geographical regions and cultural groups for further better understanding of cultural impact on career decision especially in the case of students with family business background where there are more moderators and more choices. Following this direction, future studies might derive results related to higher social levels instead of analysing solely individuals.

The necessity for higher level of complexity model-wise is confirmed by the fact that several control variables in our study resulted as statistically significant 
factors. We would especially suggest that further studies should better analyse study performance and employment status during studies. Better understanding the impact of these factors on student's career decision could have significant practical implications on directing educational program on university level as well as on country level.

In our opinion, future studies of the field should address risk factors more in detail. Deriving from previous suggestions it would be advisable to analyse separately personal risk perception and perceived uncertainty both on contextual level career choice of students with family business background in their respective environments.

\section{References}

Agarwal, R., Kumar, A., \& D'Souza, K. (2016). Issues in career choicces of successors in family businesses: Perspective from literature review. Juornal of Applied Management and Investments, 5 (1), 1-19.

Ajzen, I. (1991). The theory of planned behavior. Organizational Behavior and Human Decission Processes, 50 (2), 179211.

Autio, E., Pathak, S., \& Wenneberg, K. (2013). Consequences of cultural practices for entrepreneurial behaviors. Journal of International Business Studies, 44 (4), 334362.

Barnes, L.B., \& Hershon, S.A. (1976). Transferring Power in The Family Business. Harvard Busienss Review, 54 (4), 105-114.

Baù, M., Hellerstedt, K., Nordqvist, M., \& Wennberg, K.J. (2013). Succession in Family Firms, in Sorenson, R.L., Yu, A., Brigham, K.H., \& Lumpkin, T.G. (ed.). The Landscape Of Family Business, Cheltenham, UK: Edward Elgar, 167-197.
Bezemer, D.J. (2006). Poverty in Transition Countries. Juornal of Economics and Business, 9 (1), 11-35.

Kota, H.B., \& Singh, R. (2016). Comparative analysis of family businesses with non-family businesses: Empirical evidence from India. Serbian Journal of Management, 11(1), 29-41.

Bird, B., Welsh, H., Astrachan, J.H., \& Pistrui, D. (2002). Family Business Research: The Evolution of an Academic Field. Family Business Review, 15 (4), 337350.

Blumentritt, T., Mathews, T., \& Marchio, G. (2012). Game Theory and Family Business Succession: An Introduction. Family Business Review, 26 (1), 51-67.

Bocatto, E., Gispert, C., \& Rialp, J. (2010). Family-Owned Business Succession: The Influence of Pre-performance in the Nomination of Family and Nonfamily Members: Evidence from Spanish Firms. Journal of Small Business Management, 48 (4), 497-523.

Carr, J.C., \& Sequeira, J.M. (2007). Prior family business exposure as intergenerational influence and entrepreneurial intent: A Theory of Planned Behavior approach. Journal of Business Research, 60, 1090-1098.

Chlosta, S., Patzelt, H., Klein, S.B., \& Dormann, C. (2012). Parental role models and the decision to become self-employed: The moderating effect of personality. Small Business Econimics, 38, 121-138.

Cox, D.F. (1967). Risk handling in consumer behavior - an intensive study of two cases, in Cox, D.F. (ed.). Risk taking and information handling in consumer behavior, Boston: Harvard University Press, 34-81.

Davidsson, P. (2004). Researching entrepreneurship, New York: Springer Publication. 


\title{
УСПЕХ ПОРОДИЧНОГ БИЗНИСА У ТРАНЗИЦИОНОЈ ЕКОНОМИЈИ: ПРАТИТИ ПОСЛОВНЕ ЦИЉЕВЕ ИЛИ РАДИТИ НА СВОЈ НАЧИН?
}

\author{
Предраг Љуботина, Дорис ГомезељОмерзел и Јака Вадњал
}

\begin{abstract}
Извод
Студенти са традицијом породичног пословања имају три опције када се ради о одлуци о каријери. То чини избор каријере сложенијим у поређењу са класичном дилемом између тражења запослења и започињања новог пословног подухвата. На основу ГУЕССС 2013/14 истраживања које је спроведено у 34 земље са 109000 учесника, анализиран је утицај личних фактора који утичу на избор каријере студената у земљама у транзицији и земљама са развијеном тржишном економијом у Европи. Коришћењем теорије планираног понашања, ставова о ризику и перформансама породичног пословања, разматрана је разлика између две посматране групе. Утврђено је да заједнички именитељ скоро педесет година планиране економије у земљама у транзицији утиче на намере њиховог избора каријере, посебно у смислу контроле личног понашања, субјективних норми и ставова о ризику. Налази, засновани на компаративном приступу, указују на то да је контекст окружења важан фактор утицаја који треба размотрити у даљем истраживању овог поља.
\end{abstract}

Кључне речи: породично пословање, међународно истраживање, сукцесија, транзициона економија, ГУЕССС анкета

Desislava, Y., \& Tarrazon, M.-A. (2010). Gender differences in entrepreneurial intentions: evidence from Bulgaria. Journal of Developmental Entrepreneurship, 15 (3), 245-261.

Dohmen, T., Huffman, D., Schupp, J., Falk, A., Sunde, U., \& Wagner, G.G. (2011). Individual risk attitudes: Measurement, determinants, and behavioral consequences. Journal of the European Economic Association, 9 (3), 522-550.

Douglas, E.J. (2013). Reconstructing Entrepreneurial Intentions to Identify Predisposition for Growth. Journal of Business Venturing, 28 (5), 633-651.

Douglas, E., \& Shepherd, D. (2002). Selfemployment as a career choice: attitudes, entrepreneurial intentions, and utility maximization. Entrepreneurial Theiry and
Practice, 26 (3), 81-90.

Dyer, W.G. (1986). Cultural Change in Family Firms: Anticipating and Managing Business and Family Transitions, San Francisco CA.: Jossey-Brass Publishers.

Eddleston, K.A., Kellermanns, F.W., \& Sarathy, R. (2008). Resource Configuration in Family Firms: Linking Resources, Strategic Planning and Technological Opportunities to Performance. Journal of Management Studies, 45 (1), 26-50.

Estrin, S., Hanousek, J., Kočenda, E., \& Svejnar, J. (2009). The Effects of Privatization and Ownership in Transition Economies. Journal of Economic Literature, 47 (3), 1-30.

Gartner, W.B. (1989). Some Suggestions for Research on Entrepreneurial Traits and Characteristics. Entrepreneurship: Theory 
and Practice, 14 (1), 27-37.

Habbershon, T.G., Williams, M., \& MacMillan, I.C. (2003). A unified systems perspective of family firm performance. Journal of Business Venturing, 18, 451-465.

Hair, J.F., Black, W.C., Babin, B.J., \& Anderson, R.E. (2010). Multivariate data analysis, 7th edition, Upper Saddle River: Pearson Education, Inc.

Handler, W.C., \& Kram, K.E. (1988). Succession in family firms: The problem of resistance. Journal of the Family Firm Institute, 1, 361-381.

Hofstede, G. (1991). Cultures and organizations: software of the mind, New York: McGraw-Hill.

Hofstede, G. (2003). Cultures consequences: Comparing values, behaviors, institutions and organizations across nations, Thousand Oaks: Sage Publications.

Kolvereid, L. (1996). Organizational employment versus self-employment: Reasons for career choice intentions. Entrepreneurship Theory and Practice, 20 (3), 23-31.

Krueger Jr., N.F., Reilly, M.D., \& Carsrud, A. (2000). Competing models of entrepreneurial intentions. Journal of Business Venturing, 15 (5-6), 411-432.

Krueger, N.F., \& Carsrud, A.L. (1993). Entrepreneurial intentions: Applying the theory of planned behaviour. Entrepreneurship and Regional Development, 5, 315-330.

Laspita, S., Breugst, N., Heblich, S., \& Patzelt, H. (2012). Intergenerational transmission of entrepreneurial intentions. Journal of Business Venturing, 27 (4), 414435.

Liñán, F., \& Chen, Y.-W. (2009). Development and Cross-Cultural Application of a Specific Instrument to Measure Entrepreneurial Intentions.
Entrepreneurship Theory and Practice, 33 (3), 593-617.

Lüthje, C., \& Franke, N. (2011). Entrepreneurial Intentions of Business Students: A Benchmarking Study. International Journal of Innovation and Technology Management, 1 (3), 268-288.

Morris, M.H., Williams, R.O., Allen, J.A., \& Avila, R.A. (1997). Correlates of success in family business transitions. Journal of Business Venturing, 12, 385-401.

Neubauer, F., \& Lank, A.G. (2016). The Family Business: Its Governance for Sustainability, Springer.

Olson, P.D., Zuiker, V.S., Danes, S.M., Stafford, K., Heck, R.K.Z., \& Duncan, K.A. (2003). The impact of the family and the business on family business sustainability. Journal of Business Venturing, 18, 639-666.

Pennings, J.M.E., \& Wansink, B. (2004). Channel Contract Behavior: The Role of Risk Attitudes, Risk Perceptions, and Channel Members Market Structures. Journal of Business, 77 (4), 697-723.

Podsakoff, P.M., MacKenzie, S.B., Podsakoff, N.P., \& Lee, J.-Y. (2003). Common Method Biases in Behavioral Research: A Critical Review of the Literature and Recommended Remedies. Journal of Applied Psychology, 88 (5), 879-903.

Quintal, V.A., Lee, J.A., \& Soutar, G.N. (2010). Risk, uncertainty and the theory of planned behavior: A tourism example. Tourism Management, 31, 797-805.

Ramadani, V., \& Hoy, F. (2013). Context and Uniquness of Family Business, in Dana, L.-P. and Ramadani, V. (ed.). Family Businesses in Transition Economies: Management, Succession and Internationalization, Cham: Springer.

Roaf, J., Atoyan, R., Joshi, B., Krogulski, K., \& IMF Staff Team. (2014). 25 Years of Transition Post-Communist Europe and the 
IMF: Regional economic issues special report. Washington, DC: International Monetary Fund.

Scholes, L.M., Wright, M., Westhead, P., Burrows, A., \& Bruining, H. (2007). Information Sharing, Price Negotiation and Management Buy-outs of Private Familyowned Firms. Small Business Economics, 29 (3), 329-349.

Schröder, E., Schmitt-Rodermund, E. \& Arnaud, N. (2011). Career Choice Intentions of Adolescents With a Family Business Background. Family Business Review, 24 (4), 305-321.

Senegović, I., Bublić, V., \& Ćorić, G. (2015). Family Business Succession Risks: The Croatian Context, in Dana, L.-P., \& Ramadani, V. (ed.). Family Businesses in Transition Economies: Management, Succession and Internationalization, Cham: Springer.

Sharma, P., Chrisman, J.J., \& Chua, J.J. (2003). Predictors of satisfaction with the succession process in family firms. Journal of Business Venturing, 18 (5), 667-687.

Shirokova, G., Oleksiy, O., \& Karina, B. (2016). Exploring the intention-behavior link in student entrepreneurship: Moderating effects of individual and environmental characteristics. European Management Journal, 34 (4), 386-399.

Wennekers, S., Van Stel, A., Thurik, R. \& Reynolds, P. (2005). Nascent Entrepreneurship and the Level of Economic Development. Small Business Economics, 24, 293-309.

Williams Jr., R.I. (2015). Measuring Family Business Performance: A Holistic, Idiosyncratic Approach, Kennesaw State University.

Zahra, S.A. (2005). Entrepreneurial Risk Taking in Family Firms. Family Business Review, 18 (1), 23-40.
Zellweger, T.M., Kellermanns, F.W., Chrisman, J.J., \& Chua, J.H. (2012). Family Control and Family Firm Valuation by Family CEOs: The Importance of Intentions for Transgenerational Control. Organization Science, 23 (3), 851-868.

Zellweger, T., Sieger, P., \& Halter, F. (2011). Should I stay or should I go? Career choice intentions of students with family business background. Journal of Business Venturing, 26 (5), 521-536. 